\title{
Vulnerable Here or There? Examining the vulnerability of victims of human trafficking before and after return
}

\author{
Erlend Paasche, May-Len Skilbrei and Sine Plambech
}

\begin{abstract}
This article deals with how return programmes for rejected asylum seekers and irregular migrants construct and create vulnerabilities. Few studies have explored the role of assistance provided through such programmes for the sex worker returnees and victims of trafficking who return through them. Even fewer holistically examine a return programme through data elicited in both destination and origin locations, before and after return. That is what we aim to do in this article. We first look at the legal-bureaucratic construction of vulnerability in a host state, Norway, and the systemic logic of its efforts to return victims of trafficking. We then look at how returnees narrate their experiences of and perspectives on vulnerability upon return to their country of origin, Nigeria. This study, together with the broader research within this field, indicates that flaws in programme implementation can in fact exacerbate vulnerabilities rather than help returnees overcome them.
\end{abstract}

Keywords: human trafficking, vulnerability, return, reintegration, IOM, Nigeria

Please cite this article as: E Paasche, ML Skilbrei and S Plambech, 'Vulnerable Here or There? Examining the vulnerability of victims of human trafficking before and after return', Anti-Trafficking Review, issue 10, 2018, pp. 34-51, www.antitraffickingreview.org

\section{Introduction}

Migration control is framed as both tough and kind. On the one hand, European governments have shifted migration policies in a stricter direction to ensure that they appear to be 'tough on migrants', with the stated intention of deterring migrants from travelling to a particular country and making them leave if they fail to secure a residency permit. ${ }^{1}$ Norway, a member of the Schengen free travel area and Dublin Regulation, exemplifies this. ${ }^{2} \mathrm{~A}$ restrictive turn in Norwegian asylum policy has emerged since the turn of the millennium and across four governments, evident in the steep increase in deportations. ${ }^{3}$

On the other hand, the return of rejected asylum seekers and irregular migrants is also framed in the humanitarian language of migration management and humanitarian assistance-of helping migrants to 'come home'. Labelled 'Assisted Voluntary Return and Reintegration programmes' (AVRRs), such programmes incentivise return while presenting it as 'voluntary'. This serves to make them acceptable for domestic electorates as well as states of origin. Funded by host states, AVRRs are typically implemented by the International Organization for Migration (IOM) - whose recent promotion in 2016 to become the UN Migration Agency is at least partly the result of its dominance of the return industry. Critics often point out that the alternative to 'voluntary' return, deportation, means that AVRRs cannot be meaningfully described as voluntary. ${ }^{4}$ The relationship between the threat of deportations and AVRRs hence constitutes a carrot and stick strategy.

1 N Sigona, 'The Contested Politics of Naming in Europe's "Refugee Crisis", Ethnic and Racial Studies, vol. 41, issue 3, 2018, pp. 456-60; K F Aas, 'Bordered Penality: Precarious membership and abnormal justice', Punishment \& Society, vol. 16, issue 5, 2014, pp. 520-41.

2 The Schengen agreement establishes a border-free zone between its 26 member states and a joint responsibility for the protection of the zone's outer border. The Dublin Regulation establishes a 'burden sharing' principle among its member states and regulates their obligations towards asylum seekers.

3 Aas, 2014.

$4 \quad$ F Webber, 'How Voluntary are Voluntary Returns?', Race \& Class, vol. 52, issue 4, 2011, pp. 98-107. In Norway, the government changed the term to 'assisted return' in June 2014. 
In 2016, IOM offered return assistance to more than 98,000 migrants worldwide. This is the highest number of 'AVRR beneficiaries', as the agency describes them, during the past 15 years. It constitutes an increase of 40 per cent from 2015, which already marked a significant increase in comparison to previous years. ${ }^{5}$ AVRRs come in many varieties. They may include plane tickets, financial support, counselling and information by the IOM or staff at the asylum reception centre, and in-kind assistance to set up a small business in the country of origin. Other types of support, like support for housing, medical assistance and education, are comparatively rare. The scope and type of assistance available in AVRRs vary significantly across funding states and depend on programme design and eligibility criteria. Efforts to make AVRRs increasingly sophisticated and targeted can be seen as a neoliberal tactic to make responsible unruly migrants and entice them into collaboration by formulating their problems, and therefore their solution, as individual. ${ }^{6}$

Yet, despite the massive investments in AVRRs, we know little about how they affect reintegration. ${ }^{7}$ The scholarly work produced on the impact of AVRRs on reintegration outcomes is very limited. ${ }^{8}$ Migration scholarship demonstrates that returnees face several problems after return across multiple assistance programmes. This is not least true for victims of trafficking. ${ }^{9}$ Synthesising the knowledge within this field, an International Labour Organization (ILO) report points out that, in general, 'returning home carries with it a complex set of difficulties for victims of trafficking. Many face the same pressures upon return that had prompted their departure.' 10 A study among female sex workers deported from Europe to Benin City, concluded that, 'Whereas in Europe, the women were vulnerable to deportation, back in Benin the women were vulnerable because of deportation.'11

The focus in this article is on differentiations made in how assisted return is spoken about and practised, particularly with regard to how the term 'vulnerable' is made operational. Scholarship in the field of trafficking has demonstrated how the designation of migrant sex workers as vulnerable per se has served as a lever for punitive approaches to sex work and 'armed love' towards victims of trafficking, to use Ticktin's term. ${ }^{12}$ This mandates that scholars empirically investigate how it is put to use.

Few studies explore the role of AVRRs in the return and reintegration process of sex worker returnees and victims of trafficking, and even fewer holistically examine a return programme through data elicited both in origin and destination locations, before and after return. ${ }^{13}$ This is what we attempt to do in this article. Following a brief note on methods, we look at how the label 'vulnerable' is applied to victims of trafficking in Norway in the context of recruitment into a needs-based return programme. ${ }^{14}$ We then look at how returned Nigerian victims of trafficking narrate their experience of and perspectives on vulnerability.

International Organization for Migration, Assisted Voluntary Return and Reintegration, 2016 Key Highlights, IOM, Oslo, 2017.

6 R Andrijasevic and W Walters, 'The International Organization for Migration and the International Government of Borders', Environment and Planning D: Society and Space, vol. 28, issue 6, 2010, pp. 977-99.

7 E Paasche, Why Assisted Return Programmes must be Evaluated, Peace Research Institute Oslo (PRIO) Policy Brief 08/2014.

$8 \mathrm{~K}$ Koser and K Kuschminder, Comparative Research on the Assisted Voluntary Return and Reintegration of Migrants, IOM, Geneva, 2015.

9 V Nikolic-Ristanovic, 'What Victims Went Through and How They Survived' in L Bjerkan (ed.), A Life of One's Own: Rehabilitation of victims of trafficking for sexual exploitation, Fafo, Oslo, 2005; A Brunovskis and R Surtees, Leaving the Past Behind? When victims of trafficking decline assistance, Fafo, Oslo, 2007; J Pennington and B Balaram, Homecoming: Return and reintegration of irregular migrants from Nigeria, Institute for Public Policy Research, London, 2013; S Plambech, "'God Brought You Home"-Deportation as moral governance in the lives of Nigerian sex worker migrants', Journal of Ethnic and Migration Studies, vol. 43, issue 13, 2017, pp. 2211-27.

10 A Lisborg and S Plambech, Going Back-Moving on: A synthesis report of the trends and experiences of returned trafficking victims in Thailand and the Philippines, ILO, Bangkok, 2009.

11 S Plambech, 'Between "Victims" and "Criminals": Rescue, deportation and everyday violence among Nigerian migrants', Social Politics, vol. 21, issue 3, 2014, p. 395.

12 S A FitzGerald, 'Vulnerable Geographies: Human trafficking, immigration and border control in the UK and beyond', Gender, Place \& Culture, vol. 23, issue 2, 2016, pp. 181-97; P Kotiswaran, 'Vulnerability in Domestic Discourses on Trafficking: Reflections on the Indian Experience', Feminist Legal Studies, vol. 20, issue 3, 2012, pp. 245-62; M Ticktin, Casualties of Care: Immigration and the politics of humanitarianism in France, University of California Press, Berkeley, 2011.

13 For an exception, see: S Plambech, Points of Departure. Migration control and anti-trafficking in the lives of Nigerian sex worker migrants after deportation from Europe, Ph.D. dissertation, Department of Anthropology, University of Copenhagen, 2014, covering Denmark and Nigeria.

14 Points in this section, while revised and shortened, are also presented in E Paasche and M L Skilbrei, 'Gendered Vulnerability and Return Migration', Temida vol. 30, issue 2, 2017, pp. 149-66. 


\section{Background}

Some AVRRs in Norway are country-specific, but most returnees make use of a universally available programme called 'Financial Support for Return' (FSR). Another programme of special interest in this article is entitled 'Information, Return and Reintegration for Vulnerable Migrants in Norway', also referred to as the 'Vulnerable Groups Project' (VG). The VG programme differs from the FSR programme by being comparatively more generous, as outlined in table 1 below. It is also designed to offer follow-up counselling and monitoring in the country of origin for the duration of one year. Similar programmes for migrants deemed vulnerable also exist elsewhere in Europe. Although only approximately three per cent of those who received support through an AVRR from the IOM in 2016 were designated migrants in vulnerable situations, numbers alone do not detract from their importance. In IOM's wording, 'specific and tailored assistance is particularly critical for returning migrants in vulnerable situations...' ${ }^{15}$

Table 1. The assistance on offer in the FSR and VG programmes

\begin{tabular}{|c|c|c|}
\hline $\begin{array}{l}\text { Programme / } \\
\text { aid components }\end{array}$ & $\begin{array}{l}\text { Financial Support to Return } \\
\text { (FSR) }\end{array}$ & $\begin{array}{l}\text { Vulnerable Groups } \\
\text { (VG) }\end{array}$ \\
\hline $\begin{array}{l}\text { Flights to country of origin, free } \\
\text { of charge }\end{array}$ & Yes & Yes \\
\hline $\begin{array}{l}\text { Consulting with IOM } \\
\text { pre-return }\end{array}$ & Yes & Yes \\
\hline Cash grant & $\begin{array}{l}\text { Yes. Up to 2,600 USD for adults } \\
\text { upon arrival and } 1,300 \text { USD per } \\
\text { child. }\end{array}$ & Yes. 1,000 USD upon arrival. \\
\hline $\begin{array}{l}\text { In-kind assistance } \\
\text { (i.e. non-cash) }\end{array}$ & No & $\begin{array}{l}\text { Yes. 4,500 USD for housing, } \\
\text { medicine, health services, } \\
\text { education, or starting a business. }\end{array}$ \\
\hline $\begin{array}{l}\text { Follow-up counselling and } \\
\text { monitoring by IOM in the } \\
\text { country of origin post-return }\end{array}$ & $\mathrm{No}$ & Yes. Duration of one year. \\
\hline
\end{tabular}

In Norway, one form of vulnerability that has been especially relevant in the context of assisted return relates to being trafficked. ${ }^{16}$ Nigerians represented by far the largest national group of 'possible victims of human trafficking' in Norway in 2016. ${ }^{17}$ At the same time, the rejection rate for Nigerian asylum seekers was 94 per cent that year, and has been high since $2010 .^{18}$

Being a victim of trafficking does not necessarily warrant asylum or a residence permit on humanitarian grounds. The immigration authority in Norway clearly states in a legal memo on asylum practices for Nigerian applicants that having been trafficked does not in itself constitute grounds for protection and that 'an individual assessment must be made of the risks an applicant faces upon return'. ${ }^{19}$ Yet, Norway is legally obliged to protect victims, for instance through the UN Trafficking Protocol and the Council of Europe Convention on Action against Trafficking in Human Beings. The latter specifies in article 16.2 that the return of victims 'shall preferably be voluntary' and that it 'shall be with due regard for the rights, safety and dignity of that person...'. It is a challenge, then, that Nigerians consistently rank at the top of statistics on deportations and expulsions from Norway. GRETA, the monitoring body for the Convention, has criticised Norway for not doing enough to prevent victims being returned unscreened and in breach of the principles of the Convention. ${ }^{20}$

15 IOM, 2017, p. 11.

16 E Paasche, S Plambech and M L Skilbrei, Assistert retur til Nigeria, University of Oslo, Oslo 2016.

KOM, Rapport fra Koordineringsenheten for Ofre for Menneskehandel, KOM, Oslo, 2017.

E Paasche, S Plambech and M L Skilbrei, 2016.

Utlendingsdirektoratet, Memo on Practices and Procedures, Document PN 2011-002, 2017a, authors' translation.

20 GRETA, Report Concerning the Implementation of the Council of Europe Convention on Action against Trafficking in Human Beings by Norway, Second evaluation round, Council of Europe, Strasbourg, 2017, pp. 32-3. 
Norway's international obligations hence give impetus to providing victims of trafficking with additional assistance and monitoring upon return; so does the cost-efficiency of effectuating return rather than covering the costs of catering to the basic needs of socioeconomically disadvantaged migrants. As Norway's minister of migration and integration, Sylvi Listhaug, expressed in a personal tweet regarding the costs of AVRRs: 'We'll pay them a little extra, but save the state money because it costs a lot to have people at the asylum centre. ${ }^{21}$ The Norwegian government has identified the low uptake of victims of trafficking in the VG programme as a problem. ${ }^{22}$ While victims of trafficking who are rejected asylum seekers rarely are sufficiently vulnerable to fulfil the eligibility criteria for asylum, they may well be sufficiently vulnerable to qualify for the VG support.

\section{Methods}

This article is based on research that the authors conducted with funding from the Norwegian immigration authorities in 2015 and 2016. The primary objective of the research was to assess the effects and efficiency of the FSR and VG programmes for Nigerian nationals, and to identify room for improvements. An ongoing and larger research project, Transnationalism from above and below: Migration management and how migrants manage (MIGMA), has enabled us to deepen our analysis of those data.

In Norway, data consists of 32 interviews with individuals who, in a professional capacity, inform rejected asylum seekers and irregular migrants from Nigeria about their legal obligation to return, as well as the options of assisted and forced return available to them. These professionals were IOM staff members, personnel at asylum reception centres and social workers in public and private outreach organisations. We also interviewed two Nigerian prospective returnees and fifteen Nigerian nationals who had applied for asylum, five men and ten women. Of these, four awaited an asylum decision at the time of the interview, while the rest were rejected asylum seekers who contemplated or had applied for assisted return. All were adults, and several of the women had accompanying children and/or had a status as a victim of trafficking. We recruited interviewees through networks established from previous research, NGOs and migrant-centred organisations, and through five asylum reception centres. The interviews with Nigerian migrants were conducted in English without the use of an interpreter, lasted between 30 and 90 minutes, and took place at the interviewees' residence, in the offices of a civil society organisation offering assistance to migrants, or in a reception centre. A methodological challenge that arose during interviews with the migrants in Norway concerned the sensitivity of the issue of return. Asylum migrants interviewed by a Northern researcher at a Northern location can be expected to both feel morally obliged and consider it in their interest to provide a coherent asylum narrative, adjusting their narrative to legal-bureaucratic imperatives. ${ }^{23}$ They hence have strategic reasons to overcommunicate their inability to return. Those who had already signed up for assisted return, either through the FSR or VG programmes, were more eager to talk of their future lives after return.

In Nigeria, the fieldwork lasted for one month. ${ }^{24}$ While we did some key informant interviews in Abuja and Lagos, we focused data gathering in Benin City in Edo State, as it is known to be a major sending region for irregular migrants and victims of trafficking to Europe. We interviewed sixteen Nigerians who had returned from Norway. Among these, twelve had returned through the universal FSR programme (nine telephone interviews and three interviews face to face) and four had returned through the VG programme (three telephone interviews and one face to face).

Despite the low representation of VG returnees in the collected data, the narratives of these four women are strikingly similar. Discussions of post-return vulnerabilities moreover draw on two useful data sources. Firstly, we conducted eighteen interviews with female sex workers who had returned from other European countries. Whether they were deported or had returned through AVRRs was often hard to elicit from interview data, and did not appear relevant to the majority. We recruited these interviewees through local NGOs. Both the NGOs

21 See: R Seales, 'Migrants in Germany: Should they be paid to go home?', BBC, 15 December 2017, retrieved 5 January 2018, http://www.bbc.com/news/world-europe-42235232. BBC's translation.

22 Norwegian Ministry of Justice and Public Security, Governmental Action Plan against Human Trafficking, 2016, p. 15.

23 M Eastmond, 'Stories as Lived Experience: Narratives in forced migration research', Journal of Refugee Studies, vol. 20, issue 2, 2007, pp. 248-64.

24 Fieldworks in Norway and Nigeria were conducted by May-Len Skilbrei and Erlend Paasche respectively. 
and the interviewee received NGN 8,000 (then equivalent to approximately EUR 40) as compensation for allocating staff time to aid recruitment, offering facilities as a venue for the interview, and the interviewees' transportation costs and loss of income from being absent from their work place. While a commercial interest can be problematic in terms of research ethics, we considered it appropriate, as the interviewees were asked to talk about deeply personal experiences of hardship and loss. A token of appreciation is expected as standard practice for journalists and academics who come to Benin City to interview victims of trafficking. ${ }^{25}$

Secondly, we conducted 26 key informant interviews with representatives from organisations and agencies working to facilitate the return and reintegration of victims of trafficking in Nigeria. These were professionals in local NGOs, federal agencies like The National Agency for the Prohibition of Trafficking in Persons (NAPTIP), international agencies like the IOM and United Nations Office on Drugs and Crime (UNODC), and migration attachés at European embassies from states with high levels of Nigerian victims. On top of this, the article also draws on research by the authors on Nigerian migrant sex workers, on the reintegration of victims of trafficking in Nigeria and elsewhere, and on AVRRs more broadly. ${ }^{26}$

\section{Pre-return: The legal-bureaucratic construction of vulnerability in Norway}

Rejected asylum seekers and irregular migrants are at the margins of the host state. They typically receive very limited welfare and face poor future prospects following a failed investment of time and money in asylum migration. A great number have little to return to at origin locations but disappointed and indebted sending households. It is hence not straightforward how one goes about applying the label of 'vulnerable' on a select group of rejected asylum seekers. While a definition of vulnerability may seem useful for determining who should access additional assistance, the need for clear definitional criteria must be balanced against the need for flexibly accommodating individual needs on a case-by-case basis. Yet, some vulnerabilities are more flexibly accommodated than others.

Our data indicates that conceptual blind spots among immigration authorities, frontline personnel and migrants themselves produce a gendered hierarchy of vulnerabilities. The vulnerability of female victims of trafficking for the purpose of prostitution, we argue, appears on top of this hierarchy. Both FSR and VG support must be applied for by the prospective returnee, and eligibility is determined by the IOM in collaboration with the Norwegian Directorate of Immigration (UDI). Nonetheless, social workers and other professionals can directly recommend individual migrants for particular consideration, or indirectly present their case in such a way that vulnerability is emphasised, and allows migrants to do so too.

UDI lists some forms of vulnerability on its website. These include being a victim of violence, force or exploitation; having special health needs; and being single and above the age of 60 . While this list offers a roadmap for the IOM, its staff members described the evaluation of vulnerability as complex. One individual may be disadvantaged in multiple ways, and it is the sum of these challenges that must be assessed holistically to determine eligibility. At the time of the interview with IOM staff members in 2015, the VG programme had almost exclusively been used by female victims of trafficking for the purpose of prostitution. Victims of trafficking for other purposes are not offered assistance to the same degree. ${ }^{27}$

Low uptake in the VG programme has both normative and institutional reasons. When asked directly, most professionals emphasised their sensitivity to the vulnerability of female victims of trafficking for prostitution. Some reflected that they did not associate masculinity with vulnerability. Others noted, when asked to reflect on alternative forms of vulnerability, that they had unconsciously associated the VG programme only with

25 Mostly, people in Benin City refer to anyone who has returned unwillingly as 'deported'. S Plambech, 'Between "Victims" and "Criminals".

26 See, for instance: M L Skilbrei and M Tveit, Facing Return: Perceptions of repatriation among Nigerian women in prostitution in Norway, Fafo, Oslo, 2007; S Plambech, Points of Departure; S Plambech, 'Sex, Deportation and Rescue: Economies of migration among Nigerian sex workers', Feminist Economics, vol. 23, issue 3, 2016, pp. 134-59; A Strand, S K N Bendixsen, H Lidén, E Paasche and L Aalen, Programmes for Assisted Return to Afghanistan, Iraqi Kurdistan, Ethiopia and Kosovo: A comparative evaluation of effectiveness and outcomes, Chr. Michelsen Institute, Bergen, 2016; E Paasche, Why Assisted Return; Lisborg and Plambech, 2009.

27 M L Skilbrei, 'Moving Beyond Assumptions? The framing of anti-trafficking efforts in Norway' in R Sollund (ed.), Transnational Migration, Gender and Rights, Emerald Insight Publishing, 2012, pП. 211-27; KOM, 2017. 
victims of trafficking for prostitution-who are overwhelmingly female as per available statistics. In general, trafficking is most commonly associated with female and minor victims. One reason might be that many male victims of trafficking are reluctant to self-identify. ${ }^{28} \mathrm{~A}$ review of trafficking policies in Norway has demonstrated that while the exploitation of men and labour exploitation more often appears the target of policies on paper, little has happened in terms of concrete steps. ${ }^{29}$ Social workers employed in public and private organisations that do outreach among sex workers are especially sensitive to this channel to extra reintegration assistance. Others, such as the quarter of identified victims of trafficking for other purposes in Norway, ${ }^{30}$ consequently lack access not only to similar support while in Norway but also upon their return to their country of origin. Lack of self-identification as a victim thus exacerbates the shortcomings in current institutionalised responses that are more likely to discover and identify trafficking cases involving females than males. Nigerian migrants and professionals might likewise not contest such gendered practices.

In informing migrants about the VG programme, asylum reception staff and social workers alike are faced with a dilemma: to inform about a generous programme available to a select few or keep things simple and merely encourage migrants to contact the IOM for further information. Most asylum seekers, including many rejected ones, are unwilling to talk with asylum reception staff and social workers about return for fear of jeopardising their claim for protection. While not disputing that migrants should be aware of their options, many professionals found it most sensible to first encourage contact with the IOM, so the migrant could ask for more information from the agency directly. As one specialised return counsellor put it: 'It takes a lot to even get them to meet with the IOM.' Offering information on the intricacies of differentiated assistance components is thus less of a priority. There is also a perceived risk that unrealistic expectations of eligibility for an exclusive VG programme could cause disappointment and make applicants think twice about returning.

The downside of this approach is that it leaves migrants heavily dependent on the IOM, a stakeholder contracted by the Norwegian state and under pressure to produce high return rates, to offer accurate and unbiased information to migrants. A small-n study on assisted return in Norway found that even migrants who had enlisted with one of IOM's return programmes did not seem properly informed about the VG programme. $^{31}$

Finally, for reasons that will be made clearer in the next section, it is not a foregone conclusion that all prospective returnees actually prefer the VG support over the FSR support. While the VG support is more generous in the value of assistance on offer, migrants may have their own reasons to prefer a simple and oneoff cash grant. As a representative of an organisation that works with rejected asylum seekers and irregular migrants noted: 'What we see, and this is not only the case for Nigerians, also for other groups, is that...it is easier to choose the cash benefit.' IOM staff members emphasised that they inform returnees about their options, but leave it to the migrant to decide what is preferable. In the words of one interviewee: 'We do not want to pressure someone into that programme, they have the option of choosing a normal track with the cash benefit, if that is what they want.' Migrants may, in other words, follow a logic that differs from that of the state.

\section{Post-return: The vulnerabilities of victims of trafficking back in Nigeria}

We have already touched briefly upon the spatiotemporal complexity of channelling migrants into the categories of 'vulnerable' and 'non-vulnerable'. Caseworkers in Norway need to project vulnerability temporally into the future and spatially from Norway to Nigeria. Yet, they also need to conceive of that post-return vulnerability in Nigeria as temporary. The underlying logic of the VG programme is that migrants can and should overcome their vulnerability, turning it into a phase to pass through.

In the following discussion on post-return vulnerabilities, we question the premise that VG assistance will help VG returnees overcome their vulnerability. Firstly, we identify serious problems in IOM's delivery of that assistance. Secondly, we argue that the social embeddedness of vulnerability-isolation and stigmatisation-

\footnotetext{
R Surtees, 'Trafficked Men as Unwilling Victims', St Antony's International Review, vol. 4, no. 1, 2008, pp. 16-36. M L Skilbrei, 2012.

Ibid.

C Øien and S Bendixsen, Det Riktige Valget? Motivasjon og beshutningsprosess når avviste asylsokere velger retur, Fafo, Oslo, 2012.
} 
makes it difficult to overcome vulnerability through assistance. Finally, since post-return vulnerability is largely attributable to a failed migration, its main cause becomes the return itself.

During interviews in Nigeria with victims of trafficking who had returned from Europe and Norway, administrative delays on IOM's part came up often. Previous research on this matter, in Nigeria and elsewhere, likewise shows post-return service delivery to be greatly complicated by verification procedures and anticorruption controls. ${ }^{32}$

Three VG returnees stated that it was difficult for them not to know exactly when the assistance would be forthcoming from the IOM. Consider how one of them described her major challenges after coming back, turning IOM's performance 'here' and 'there' into emblematic symbols of Europe and Nigeria.

Things work there, they don't work here. It was hard for me to find a place that I could rent for my business. I did eventually find a venue for rent, but then the IOM didn't give me the money in time. I had to wait for two weeks from the moment I asked for it from the IOM. That was too long [for the landlord]. Someone else got it.

Two VG returnees from Norway reported that assistance was not forthcoming until they managed to get the IOM's office in Norway to put pressure on the IOM's office in Nigeria. ${ }^{33}$ The same informant as above also said she had relied on IOM's office in Norway for support.

The last instalment of the money [cash grant] was supposed to be paid on Friday, but on Monday I had to call IOM in Norway to ask for it. IOM in Norway had to contact IOM in Nigeria. Then they paid the next day. If I wouldn't have called, who knows how long I would have had to wait.

The second VG returnee saw frustrating delays as unprofessional and disrespectful. Instalments would come weeks or months after the agreed date and although she established multiple bank accounts, none of them seemed to work for the IOM. She instead had to make repeated, costly visits to the IOM's office to complain, urge them to speed up their services, threaten to report the delays to the IOM's office in Norway or international media, and collect cheques that were long overdue. As a direct consequence of the delays, she noted, the business had failed because she could not buy the goods she needed in time for the high season when there was profit to be made, and her children were no longer in school because she had not been able to pay school fees on time. While she held that the local IOM office was keen to exert what it calls 'controlling and monitoring', taking photos of her in front of her residence and asking her to fill out forms, it was fundamentally unhelpful.

A returnee is a condemned person in Nigeria, not just by the people and the community, but by the IOM itself. If you're a returnee, it's like you're nothing.... I cry a lot. I shed tears a lot, when someone looks down on me.

The same informant reported that IOM's procedures made things difficult for her. For instance, a valuable household item that she had purchased through the IOM as in-kind assistance was not purchased in her name but in IOM's name, meaning that she could not document her ownership over it. Another household item that was purchased through the IOM as in-kind assistance was excessively expensive, she said, because the IOM insisted on buying it in a place where prices were high. She expressed surprise that IOM can cover medical bills as part of its reintegration assistance, and stated that if she had heard of it, she could have made good use of it. At the time of interview, she was considering selling her business, engaging in prostitution again, and remigrating to Europe. In her opinion, this was common for returnees. Those who said they did not want to go

32 For a general discussion, see: E Paasche, Corruption and Migrant Returns: Managing risk in assisted return programmes, U4 Brief 2018:1, U4, Chr. Michelsen Institute, Bergen, 2018. For examples, see: A Strand et al., Programmes for Assisted Return, 2016; S Plambech, Points of Departure, 2014, pp. 30-1.

33 In our correspondence with the IOM's office in Nigeria, we had to do the same to access the relevant contact information needed to conduct the evaluation-including not only the contact information of FSR and VG returnees but also the contact information of the local IOM office. 
back to Europe often expressed pride in it during interviews, implying that it is something unusual. 'I've decided to stay here because I'm strong.' Extant studies confirm that many aspire for remigration. ${ }^{34}$

Two of the four VG interviewees contrast their positive impression of IOM in Norway with a negative impression of IOM in Nigeria. The latter rarely came across in interviews as service-minded. Interviews with FSR returnees who struggled disproportionately to obtain a simple cash grant, seem to corroborate the impression of a sluggish organisation that is not eager to cater to the needs of returnees. ${ }^{35}$

One VG interviewee complained that the information she had received from IOM Oslo, which she described as key to the decision to sign up for VG return, was false.

One of the reasons that motivated my return was the financial assistance.... It was only when I landed here I realised that this was not going to be cash in hand.... The rest of the money, they said, I would get when I would come up with an action plan [business plan]. I have written an action plan and sent it to IOM's office here a month ago, and I have still not heard anything from them.... I wake up in the morning and do nothing.

While this in theory could be attributable to anything from poor listening skills to wilfully inaccurate information from IOM in Norway, it is clear that she would have preferred cash over the in-kind type of assistance and that she was surprised by the in-kind nature of the assistance.

Moving on from what appears as weaknesses in programme implementation, we also see the social embeddedness of post-return vulnerabilities as a second reason to question the relevance of VG support to overcome them. ${ }^{36} \mathrm{~A}$ number of studies describe the stigmatisation, socioeconomic marginalisation and alienation of returned sex workers in Benin City. ${ }^{37}$ Consistent with such observations, returnees in our study describe the devaluation of social capital upon return. As one deportee from Europe noted:

When I was deported I was empty-handed. In 2014, I came back. I cried. I'm even ashamed of going to my village. Most of them know that I went to Europe... I was ashamed to tell my mother [that I'm back].... Until now I haven't told my mother.

Some interviewees from Europe stressed how hard it was to avoid rumours and ostracisation upon their 'homecoming'. 'I don't think you can keep such things secret. If a person is [returned] a few days ago, you can hear people talking about it.' Correspondingly, several were very careful with whom they shared their experiences. 'I tell [my younger siblings] my whole story, the full experience. They will keep it as a secret. They will not tell others. We need to help ourselves.'

A general theme in interviews with victims coming back from Norway and other European states without acquiring the expected wealth, was the relative lack of family support and condemnation from dear ones. This appears to constitute an urgent and consequential vulnerability. Livelihood opportunities are scarce and patronage is a key principle of social organisation. NGO staff workers described family reunification as vital for reintegration but also as a major challenge. NGOs reported making routine risk assessments of families before advising for or against family reunification.

Decisions to migrate and investments in migration were often made at the household level. ${ }^{38}$ It frequently involved heavy debts that were now next to impossible to pay. Return spells the end of remittances, both a

34 S Plambech, Points of Departure, p. 46; E Ratia and C Notermans, "I was Crying, I did not Come Back with Anything": Women's experiences of deportation from Europe to Nigeria', African Diaspora, vol. 5, issue 2, 2013, p. 159; J Pennington and B Balaram, p. 23.

35 E Paasche, S Plambech and M L Skilbrei, 2016.

36 See: R Ruben, $M$ van Houte and T Davids, What Determines the Embeddedness of Forced-Return Migrants? Rethinking the role of pre- and post-return assistance', International Migration Review, vol. 43, issue 4, 2009, pp. 908-37.

37 S Plambech, "Between "Victims" and "Criminals"; E Ratia and C Notermans, 2013, pp. 155, 157; J Pennington and B Balaram, pp. 4, 26, 37; M L Skilbrei and M Tveit, 2007, p. 56.

38 M L Skilbrei and M Tveit, 'Mission Impossible? Voluntary and dignified repatriation of Nigerian victims of trafficking', in TD Truong and D Gasper (eds.), Transnational Migration and Human Security. Hexagon Series on Human and Environmental 
substantial contribution to the household economy and a source of social pride, and turns returnees into economic burdens instead of breadwinners. ${ }^{39}$ The visibility of some vastly enriched migrant-sending households continues to motivate migration, although the economic and social costs of failure have become more readily observable in Benin City lately.

Families were not uniformly dismissive. As one returnee from Europe said, 'My family was happy to see me. When I told her what I'd been through, my mother said that she did not care about the other, successful girls.' Another returnee described mixed feelings.

When I came back they told me that they were hungry. They needed the money. They were happy to see me initially, but expected me to bring more money, that things would be different for the family. But there was no money.

The expectation to extend patronage upon return is so powerful that several returnees, from Norway and other European countries, reported that their businesses failed because they had felt compelled to take the money needed to maintain the business in order to give it to kin and friends as gifts. This, of course, undermined the longevity of their business. Key informants saw this as a serious operational challenge.

Finally, the overall impression from the interview data suggests that non-migrants tend to attribute the failure to thrive in Europe not to systemic factors, like restrictive immigration policies, but rather to individual personality and moral shortcomings. While the stigma of returning as a female victim of trafficking for prostitution is complex, the individualisation of failure adds to that stigma and undermines returnees' support networks. Those networks are almost certainly more important for returnees' wellbeing in the long term than the limited VG support.

\section{Conclusion: Return to vulnerability}

Vulnerability is determined for prospective returnees while they are still in Norway but projected across timeinto the future-and space-into Nigeria. Data in Norway and Nigeria traverses time and space, but also analytical levels, from host state to community of origin. Some observations hold true across all of these. Vulnerability is feminised by the Norwegian host state as well as in Benin City, where the plethora of NGOs did not include a single NGO working with male victims of trafficking.

Other observations arise precisely because of our transnational methodology. It seems quite possible to be vulnerable 'there' for other reasons than 'here', for instance. While being a (female) victim of trafficking greatly increases eligibility for VG support in Norway, the vulnerability of a VG returnee in Benin City has less to do with that essentialised identity than it has to do with its practical outcomes. In other words, what material resources does the returnee bring back to the sending household? Failure to live up to expectations of patronage upon return is a major cause of vulnerability, as is ostracisation and undermined support networks. Ironically, while the VG programme makes the returnee responsible for her own welfare, the local community makes her responsible for her lack of welfare. While the category of 'victims of trafficking' is not associated with agency in Norway, returned victims of trafficking are generally held individually accountable for their situation of vulnerability — which is rarely a passing phase.

Post-return narratives of administrative delays and bureaucratic obstacles give reason for concern. This study, together with the broader research within this field, indicates that poor service delivery can in fact exacerbate vulnerabilities rather than help returnees overcome them. On the other hand, it is clear that there is a need for reintegration assistance. Our article hence raises important questions concerning the type, scope and modalities of assistance. We do not aim to resolve these questions here, but we hope our exposition can fuel debate and further research.

Security and Peace, vol. 6, Springer, Berlin, Heidelberg, 2011, pp. 135-45, p. 138; See also: E Paasche, S Plambech and M L Skilbrei, 2016.

39 S Plambech, 2016, p. 149. 
Erlend Paasche is a Post-Doctoral Fellow at the Department of Criminology and Sociology of Law, University of Oslo, in the project 'Transnationalism from Above and Below: Migration Management and How Migrants Manage (MIGMA)' on European migration management and Nigerian migration. Specialising in the field of return and reintegration, he has coauthored evaluations of assisted return programmes from Norway and conducted fieldworks in Syria, Iraq, Kosovo and Nigeria. Paasche is a visiting academic at the University of Oxford, where he analyses perspectives on trafficking among postgraduate students in Benin City, Nigeria, and representations of trafficking in Nigerian cultural production. Email: erlend.paasche@jus.uio.no

May-Len Skilbrei is Professor in criminology at the University of Oslo, where she heads MIGMA. Skilbrei has done empirical research on subjectivities in and policy developments on prostitution and human trafficking, sexual violence, irregular migration and return migration. She has coauthored the book Prostitution Policy in the Nordic Region: Ambiguous sympatbies, and has published articles on trafficking policies and victimisation in journals such as Ethnos, Anti-Trafficking Review and the British Journal of Criminology. Email: m.l.skilbrei@jus.uio.no

Sine Plambech is Senior Researcher at the Danish Institute for International Studies (DIIS) and Visiting Professor at Barnard, Columbia University, Department of Women's, Gender \& Sexuality Studies. She has extensive fieldwork experience from Nigeria, Thailand, Italy, and Denmark. She has published on trafficking, migration and deportations in journals such as Social Politics, Journal of Ethnic \& Migration Studies and Feminist Economics. She is leading the project 'Women, Sex \& Migration - Seeing sex work migration and human trafficking from the Global South' and is part of the MIGMA project. Email: spl@diis.dk 